\title{
DIVALENT CATION TRANSPORT IN KIDNEY SLICES \\ III. INHIBITORY ACTION OF VERAPAMIL ON MAGNESIUM GAIN
}

\author{
Munekazu GEMBA, Hirotaka OBANA* and Yohkazu MATSUSHIMA \\ Department of Pharmacology, Osaka College of Pharmacy, \\ Kawai, Matsubara, Osaka 580, Japan
}

Accepted January 17, 1980

It has been reported that verapamil, a substance which appears to block $\mathrm{Ca}^{2+}$ translocation across the plasma membrane (1-4), significantly increases urine flow and urinary excretion of sodium, potassium and calcium with no changes in renal blood flow and plasma electrolyte concentration (5). Our previous work indicated that verapamil inhibited not only $\mathrm{Ca}^{2+}$ accumulation but also $\mathrm{Mg}^{2+}$ accumulation by kidney cortical mitochondria (6). We suggested previously (7) that $\mathrm{Mg}^{2+}$ influx in kidney cortical slices is mediated by an energy-dependent process which is dissociated from $\mathrm{Ca}^{2+}$ flux. As little information is available concerning the effect of verapamil on $\mathrm{Mg}^{2+}$ transport through a plasma membrane, we studied the effect of verapamil on $\mathrm{Mg}^{2+}$ content of kidney cortical slices in vitro.

Male Wistar rats, weighing 180-250 g, were used in all experiments. Tissue slices were prepared from the kidney cortex as described previously (8). The slices were leached at $0^{\circ} \mathrm{C}$ for $120 \mathrm{~min}$ in $150 \mathrm{mM} \mathrm{NaCl}$ containing $0.1 \mathrm{mM}$ EDTA (disodium ethylene-diaminetetraacetate). EDTA $(0.1 \mathrm{mM})$ neutralized with $\mathrm{NaOH}(0.067 \mathrm{mM})$. After leaching, about $200 \mathrm{mg}$ of slices were incubated for $30 \mathrm{~min}$ at $37^{\circ} \mathrm{C}$ in $20 \mathrm{ml}$ of Krebs-Ringer bicarbonate buffer containing $118 \mathrm{mM} \mathrm{NaCl}, 24.9 \mathrm{mM} \mathrm{NaHCO}, 1.18 \mathrm{mM} \mathrm{KH}_{2} \mathrm{PO}_{4}, 4.74$ $\mathrm{mM} \mathrm{KCl}, 1.18 \mathrm{mM} \mathrm{MgSO}_{4}, 2.54 \mathrm{mM} \mathrm{CaCl}_{2}$ and $5.56 \mathrm{mM}$ glucose. The incubation medium was aerated with $95 \% \mathrm{O}_{2}+5 \% \mathrm{CO}_{2} . \quad \mathrm{Mg}^{2+}$ and $\mathrm{Ca}^{2+}$ content of slices were estimated using an atomic absorption spectrophotometer (Hitachi 170-10) as described in previous papers $(7,8)$. Verapamil and diltiazem were kindly provided by Eisai Co., Ltd. and Dr. T. Morita of Kanebo Co., Ltd., respectively.

Fresh kidney cortex used for experiments contained $7.22 \pm 0.11 \mu$ moles $\mathrm{Mg} / \mathrm{g}$ wet wt. and $2.11 \pm 0.06 \mu$ moles $\mathrm{Ca} / \mathrm{g}$ wet wt. When the slices were kept for $120 \mathrm{~min}$ at $0^{\circ} \mathrm{C}$ in a solution containing $150 \mathrm{mM} \mathrm{NaCl}$ and $0.1 \mathrm{mM}$ EDTA, $\mathrm{Mg}^{2+}$ and $\mathrm{Ca}^{2+}$ losses from the slices were observed, as indicated in Table 1: these being values before incubation. Aerobic incubation in Krebs-Ringer bicarbonate buffer induced an increase of $\mathrm{Mg}^{2+}$ and $\mathrm{Ca}^{2+}$ in the slices. Verapamil inhibited not only increase in the contents of $\mathrm{Ca}^{2+}$ but also that of $\mathrm{Mg}^{2+}$. Incubation with $1 \mathrm{mM}$ verapamil completely inhibited the increase of $\mathrm{Mg}^{2+}$ content during

* Present address: Laboratory of Food Chemistry, Osaka Prefectural Institute of Public Health, Osaka 537, Japan 
TABLE 1. Effect of verapamil and diltiazem on $\mathrm{Mg}^{2+}$ and $\mathrm{Ca}^{2+}$ content of kidney cortical slices

\begin{tabular}{|c|c|c|c|}
\hline \multirow{2}{*}{ Conditions } & & \multicolumn{2}{|c|}{ Tissue divalent cations ( $\mu$ moles/g wet wt.) } \\
\hline & & $\mathrm{Mg}^{2+}$ & $\mathrm{Ca}^{2+}$ \\
\hline Before incubatic & & $3.93 \pm 0.11 \quad$ (24) & $1.11 \pm 0.04$ \\
\hline \multicolumn{4}{|l|}{ After incubation } \\
\hline Control & & $5.53 \pm 0.13 \quad$ (26) & $3.53 \pm 0.07 \quad(23)$ \\
\hline \multirow[t]{3}{*}{ Verapamil } & $1 \times 10^{-4} \mathrm{M}$ & $4.60 \pm 0.06^{\mathrm{c}}(6)$ & $3.49 \pm 0.09$ \\
\hline & $5 \times 10^{-4} \mathrm{M}$ & $4.06 \pm 0.03^{c}(6)$ & $2.99 \pm 0.04^{\mathrm{c}} \quad(4)$ \\
\hline & $1 \times 10^{-3} \mathrm{M}$ & $3.82 \pm 0.09^{\mathrm{c}} \quad(6)$ & $3.07 \pm 0.04^{\mathrm{a}} \quad(6)$ \\
\hline \multirow[t]{2}{*}{ Diltiazem } & $1 \times 10^{-4} \mathrm{M}$ & $5.05 \pm 0.11^{\mathrm{b}}(12)$ & $3.36 \pm 0.10 \quad(9)$ \\
\hline & $1 \times 10^{-3} \mathrm{M}$ & $5.06 \pm 0.14^{b}(16)$ & $3.14 \pm 0.07^{\mathrm{c}} \quad(13)$ \\
\hline
\end{tabular}

The slices were leached for $120 \mathrm{~min}$ at $0^{\circ} \mathrm{C}$ in a solution containing $150 \mathrm{mM} \mathrm{NaCl}$ and $0.1 \mathrm{mM}$ EDTA before incubation. Leached slices were incubated aerobically for $30 \mathrm{~min}$ at $37^{\circ} \mathrm{C}$ in a Krebs-Ringer bicarbonate buffer. Indicated concentrations of verapamil and diltiazem were added to the incubation medium. Mean values \pm S.E. are given for the numbers of experiments shown in parentheses. a; $p<0.05$ vs. control, $\mathrm{b} ; \mathrm{p}<0.025, \mathrm{c} ; \mathrm{p}<0.005$.

the aerobic incubation. Inhibitory effects of verapamil were more potent in the case of $\mathrm{Mg}^{2+}$. While, diltiazem, another $\mathrm{Ca}^{2+}$-blocker, also inhibited the increases in levels of $\mathrm{Mg}^{2+}$, the ability to block increases in $\mathrm{Mg}^{2+}$ was considerably less than that of verapamil.

The present findings showed that $\mathrm{Mg}^{2+}$ gain was significantly inhibited by $0.1 \mathrm{mM}$ verapamil, which had no effect on $\mathrm{Ca}^{2+}$ increase in kidney cortical slices. It is noteworthy that verapamil, which has been used extensively as a $\mathrm{Ca}^{2+}$ antagonist in studies of the role of $\mathrm{Ca}^{2+}$ in biological events, exerted a significant inhibitory effect on the maintenance of the $\mathrm{Mg}^{2+}$ content in rat kidney cortical slices. Our results suggest that verapamil has a direct effect on the flux of $\mathrm{Mg}^{2+}$ in the cortical slices. The magnitude of this effect in other tissues remains to be investigated.

We found that increases in $\mathrm{Mg}^{2+}$ in kidney cortical slices are mediated by an energydependent process (7) and that ATP-dependent accumulation of $\mathrm{Mg}^{2+}$ by mitochondria isolated from kidney cortex is suppressed by verapamil (6). From the present results it is difficult to compare the effect of verapamil on $\mathrm{Mg}^{2+}$ accumulation by mitochondria and that of this drug on $\mathrm{Mg}^{2+}$ increase in the slices. However, the finding that verapamil inhibited both energy-dependent processes of $\mathrm{Mg}^{2+}$ transports in slices and mitochondria should be given consideration. The metabolism of cells is affected by $\mathrm{Mg}^{2+}(9-11)$. Therefore, the effect of verapamil on biological phenomena may be due to an inhibition of $\mathrm{Mg}^{2+}$ translocation, in addition to the inhibition of $\mathrm{Ca}^{2+}$ entry into the cells.

\section{REFERENCES}

1) Fleckenstein, A. And Grün, G.: Reversible blockade of excitation-contraction coupling in rat's uterine smooth muscle by means of organic calcium antagonists (Iproveratril, D600, Prenylamine). Pflïgers Arch. 307, R26 (1969)

2) NAYleR, W.G. AND Szeto, J.: Effect of verapamil on contractility, oxygen utilization and calcium exchangeability in mammalian heart muscle. Cardiovascular Res. 6, 120-128 
(1972)

3) Martin, B.R., Clausen, T. and Gliemann, J.: Relationships between the exchange of calcium and phosphate in isolated fat-cells. Biochem. J. 152, 121-129 (1975)

4) Wróbel, J. and Michalska, L.: The effect of verapamil on intestinal calcium transport. Europ. J. Pharmacol. 45, 385-387 (1977)

5) Abe, Y., Yukimura, T., Iwao, H., Mori, N., Nakamura, J., Okahara, T. and Yamamoto, K.: Effects of EDTA and verapamil in dogs. Japan. J. Pharmacol. 28, Supp. 179P (1978)

6) Kohda, C. AND Gemba, M.: Effect of verapamil on the calcium and magnesium transports of rat kidney cortex mitochondria. Japan. J. Pharmacol. 29, 745-751 (1979)

7) Matsushima, Y. and Gemba, M.: Divalent cation transport in kidney slices. II. Magnesium transport in kidney cortex slices and effect of diuretics. Japan. J. Pharmacol. 30, 137-143 (1980)

8) Matsushima, Y. and Gemba, M.: Divalent cation transport in kidney slices. I. Properties of calcium transport in slices of rat kidney cortex and the effect of diuretics. Japan. J. Pharmacol. 29, 367-374 (1979)

9) Sugano, T. ANd NAGaI, O.: Effect of magnesium ion on brain mitochondrial respiration. J. Biochem. 70, 417-427 (1971)

10) Aguilera, A.J., KirK, K.L. and Dibona, G.F.: Effect of magnesium on sodium transport in toad urinary bladder. Am. J. Physiol. 234, F192-F198 (1978)

11) George, G.A. and Heaton, F.W.: Effect of magnesium deficiency on energy metabolism and protein synthesis by liver. Int. J. Biochem. 9, 421-425 (1978)

\title{
A RECEPTOR RESERVE OF THE ALPHA-INHIBITORY RECEPTOR FOR ALPHA-ADRENOCEPTOR STIMULANTS IN THE TAENIA CAECUM OF GUINEA PIG
}

\author{
Issei TAKAYANAGI and Yasuo KIZAWA \\ Department of Chemical Pharmacology, Toho University School of Pharmaceutical Sciences, \\ Miyama, Funabashi, Chiba 274, Japan
}

Accepted January 21, 1980

Adrenoceptors were classified as $\alpha$ - and $\beta$-receptors by Ahlquist (1). The $\alpha$-receptor is generally associated with the excitatory functions and the $\beta$-receptor with the inhibitory functions in various smooth muscles. Stimulation of the $\alpha$ - and $\beta$-receptors in intestinal smooth muscles produces a relaxation (2). Our knowledge of the receptor reserve of $\alpha$-receptor for the $\alpha$-adrenoceptor stimulants has been, however, obtained from data in the excitatory responses $(3,4)$. Little is known of the receptor reserve for the $\alpha$-agonists in inhibitory mechanisms.

Male guinea pigs, weighing 300 to $400 \mathrm{~g}$, were sacrificed by a blow on the neck and a piece $(3$ to $4 \mathrm{~cm}$ ) of taenia was removed from the caecum and suspended in a $20 \mathrm{ml}$ organ bath filled with Locke Ringer's solution ( $\mathrm{NaCl} 154, \mathrm{KCl} 5.6, \mathrm{CaCl}_{2} 2.2, \mathrm{MgCl}_{2} 2.1, \mathrm{NaHCO}_{3}$ 5.9 and glucose $2.8 \mathrm{mM}$ ) kept at $37^{\circ} \mathrm{C}$ and bubbled with air. The physiological solution also contained propranolol hydrochloride $\left(3 \times 10^{-6} \mathrm{M}\right)$ which blocks the $\beta$-adrenoceptor action of $\alpha$-adrenergic stimulants. Norepinephrine hydrochloride, epinephrine bitartarate and phenylephrine hydrochloride were used as $\alpha$-adrenoceptor stimulants and dibenamine 